\title{
IT-RELATED USAGE OF CYRILLIC SCRIPT - A STUDY CARRIED OUT AT THE ICT COLLEGE OF APPLIED STUDIES, BELGRADE
}

\author{
Gordana Jelić́ ${ }^{1}$ \\ Danica Mamula Tartalja ${ }^{2}$ (i) \\ Zorica Mihajlović ${ }^{3}$ (D)
}

DOI: https://doi.org/10.31410/ITEMA.2019.1

\begin{abstract}
Given that the English language and Latin script are a 'mother tongue' in the field of Internet technologies, there is an issue in Serbia concerning the use of Cyrillic script when it comes to teaching and learning processes in this professional community. This paper presents the results of a study carried out at the ICT College of Applied Studies in Belgrade on the usage of Cyrillic script by students majoring in Internet technologies study program. The research sample comprised students' examination papers selected from courses taught by professors who use Cyrillic script in all segments of teaching. Out of 652 students' papers, the usage of Cyrillic script accounted for 59\%. This could be regarded as a remarkable outcome having in mind the predominance of English Latin script in the IT sector. To achieve even better results, the teachers at all levels of education should use Cyrillic script.
\end{abstract}

Keywords: Field of IT, ICT College, Cyrillic Script

\section{INTRODUCTION}

$\mathrm{T}$

he issue of the usage of Cyrillic script is a topic constantly open for discussion in our society. Pursuant to the Constitution of the Republic of Serbia, which was proclaimed on November $8^{\text {th }} 2006$, "the Republic of Serbia is a state of the Serbian people and all its citizens ..." (Article 1 of the Constitution). Additionally, "the Serbian language and Cyrillic script shall be in official use in the Republic of Serbia..." (Article 10 of the Constitution). Despite these definitions of Cyrillic script and the Serbian language included in the Constitution, we have been witnessing that Latin script has been predominant in Serbian daily life.

Bearing in mind the prevalence of Latin script, we may notice that there are some initiatives by individuals and organizations aimed at changing the current situation in order to return to our original, i.e. Serbian Cyrillic script. We should mention the Association for defending the Cyrillic alphabet "Dobrica Erić", whose Statute was adopted on January $18^{\text {th }}$ 2011, as well as the "Cherish the Serbian Language" campaign, which has a broader context than the Cyrillic alphabet itself, but at the same time, it also propagates Cyrillic script. This campaign, launched on April $8^{\text {th }} 2015$, was organized by the Secretariat for Culture of the City of Belgrade, the Faculty of Philology in Belgrade and Belgrade City Library. Many celebrities from the world of sport and culture have been engaged in this campaign to highlight various messages written in Cyrillic on the posters. We also need to underline the Draft of the Cultural Development Strategy, presented by the Minister of Culture and Information, Vladan Vukosavljević, on RTS (Radio Television of Serbia), on June $10^{\text {th }}$ 2017. The Strategy should provide various incentives for the usage of Cyrillic script.

$1 \quad$ ICT College of Applied Studies, Zdravka Čelara 16, 11000 Belgrade, Serbia

2 ICT College of Applied Studies, Zdravka Čelara 16, 11000 Belgrade, Serbia

3 ICT College of Applied Studies, Zdravka Čelara 16, 11000 Belgrade, Serbia 
In this paper, we addressed the issue of the Cyrillic script usage in a special community of individuals, which has been extremely under the pressure of using Latin script, that is in the context of education at the level of colleges of applied studies in the field of information technologies (IT). More specifically, we examined the students of the state ICT College of Applied Studies (ICT College).

The Serbian language, with its corresponding Cyrillic script, is a mother tongue of most students of the ICT College. On the other hand, the path of education that these students acquire at this college is focused distinctively otherwise. In the field of IT, the "mother tongue" of the profession is English (i.e. U.S. English version), with its corresponding Latin script.

Having regard to all of the foregoing, the aim of this study was to determine, by applying quantitative and objective methods, how many of our students examined in the selected sample use Cyrillic script in the educational process at the College, in spite of all their professional orientations. A limited survey was conducted and the first results have been presented herein. This research was inspired, inter alia, by the recently published "Survey on the usage of Cyrillic script on the Internet" by Nikola Marković and Dragana Bečejski Vujaklija, PhD, which was carried out within the activity of the Informatics Association of Serbia, in February 2018.

\section{RESEARCH METHODOLOGY}

The study on the usage of Cyrillic script by a selected group of students of the ICT College relates the 2017/2018 academic year. The six subjects taught by three professors were observed. The professional courses, such as Basics of Programming 1 and Databases, as well as the academic courses, such as Business Communications, were included in the study. The courses were selected from all three years of the study programme. The students' papers written as a part of their mid-term examinations and final exams were reviewed.

The information on the script used by the students in the educational process was obtained by inspecting the students' papers. Such an inspection of students' papers provided direct and objective data. A similar method was applied by Mihajlović and Ognjanović (2006) in their research, whereby the ability of a selected group of researchers at the Vinča Institute to use databases was monitored directly. By the application of such a direct method, the questionnaires filled in by a selected group of respondents were avoided. Surveys are methods frequently used in studies and analyses of the use of computers and the Internet both worldwide and in the country (Informatics Association of Serbia, 2018; Josanov \& Djurić-Kuzmanović, 2004; Statistical Office of the Republic of Serbia 2017a, 2017b). The problem with surveys is that information is obtained indirectly.

In this study, it is necessary to point out the attitude that three professors have towards Cyrillic script. All three professors have a positive attitude towards Cyrillic script and they have been using it in teaching. In this regard, there are two professors who can be especially distinguished. These professors have forced the usage of Cyrillic script wherever and whenever possible. All the course materials prepared for students have been written in Cyrillic, all the materials prepared for mid-term examinations and final exams have been also written in Cyrillic and the exam results have been published using Cyrillic script as well. Finally, the exam marks in the students' files have been also written in Cyrillic. 
In addition to the professors' positive attitude towards Cyrillic script, it is necessary to emphasize that the ICT College has been impelling the usage of Cyrillic, as it is a state college that acts in accordance with the Constitution and the laws of the Republic of Serbia. The College's website has been made in Cyrillic. Of course, the College also has a website available in English.

\section{RESULTS AND DISCUSSION}

The study comprised 652 students' papers. Out of the total number of the students' papers reviewed, Cyrillic was used in 385 students' papers (59\%) and Latin script was used in 267 students' papers (41\%). The rankings per professors are different, as expected. The majority of students who write in Cyrillic attended the courses held by the professors who consistently use Cyrillic script themselves. The numbers and percentages of the students per professors have been given in Table 1. In our opinion, the percentage of the students who use Cyrillic is rather high, especially considering the field of work of the ICT College, i.e. the field of IT which is dominated by the English language and Latin script. Also, given the general impression that Latin script is predominant in all segments of our society and rather aggressively imposed, the obtained findings may be considered somewhat surprising, in a positive sense.

Table 1. Numbers and percentages per professors

\begin{tabular}{|l|c|c|c|}
\cline { 2 - 4 } \multicolumn{1}{c|}{} & Number of students & $\begin{array}{c}\text { Number of students, } \\
\text { Cyrillic }\end{array}$ & $\begin{array}{c}\text { Percentage of students, } \\
\text { Cyrillic }\end{array}$ \\
\hline Professor no. 1 & 279 & 203 & 73 \\
\hline Professor no. 2 & 213 & 111 & 52 \\
\hline Professor no. 3 & 160 & 71 & 44 \\
\hline Total number of students & 652 & 385 & 59 \\
\hline
\end{tabular}

Herein we will also provide more detailed information about the courses of Basics of Programming 1, Business Communications and Databases. Regarding the course Basics of Programming 1, the number of students who participated in this study was 101. Cyrillic script was used by 79 students (78\%) and Latin script was used by 22 students (22\%). As for the Business Communications course, the number of students participating in the study was 78. Cyrillic script was used by 66 students $(85 \%)$ and Latin script was used by 12 students $(15 \%)$. This is the best result obtained in favour of Cyrillic script. The least favourable result, in regard to the usage of Cyrillic script, was obtained in the Databases course. The number of students participating in this study was 160 . There were 71 (44\%) students who used Cyrillic script and 89 students (56\%) who used Latin script in their papers. In regard to this course, it should be noted that the professor uses both Latin and Cyrillic.

In the survey organized and analysed by Marković and Bečejski Vujaklija (2018), carried out within the activity of the Informatics Association of Serbia, which inspired us to examine the usage of Cyrillic script among the students of the ICT College, the organizations engaged in different fields were asked two questions as follows:

- whether they have a website in Cyrillic, and

- whether they have a national, СРБ domain registered.

The survey included 143 organizations in the field of education and science, 60 organizations in the field of information technology industry and 54 organizations engaged in the field of public administration. The organizations engaged in other fields were less represented in number, therefore, it would be unreasonable to consider them herein. The field of culture and media could serve as an example, since only 10 such organizations took part in the survey and the 
results indicated that 7 of them have their websites in Cyrillic. The highest percentage, i.e. $80 \%$, of available Cyrillic websites, was found in the public administration organizations, followed by the organizations in the field of education and science, i.e. $57 \%$.

This is quite foreseeable as the public administration must be the first one to comply with the laws of the Republic of Serbia and the percentage should have been $100 \%$. This also applies to the field of education and science. The identity of a nation should be nurtured by education through its language and script. In our opinion, the percentage of the organizations in this area of $57 \%$ is alarmingly low. In this respect, different levels of education should be distinguished and education should be separated from science as well. As for the IT organizations, out of which only $12 \%$ have their websites available in Cyrillic, which may be considered an expected outcome since, as previously stated, English and Latin script represent the norms and standards applicable to such organizations. Consequently, Latin script has been naturally and unduly transferred into the Serbian language. Hence, the organizations should be more influenced to use Cyrillic script as all the technical requirements have been provided.

In this study, we focused on the first question. If the results given in this paper are compared with those obtained by the Informatics Association of Serbia, it may be stated that the findings provided by our study on the attitude towards Cyrillic script at the ICT College are quite good. As a reminder, $59 \%$ of the students who participated in the study used Cyrillic script in the educational process, although the predominant field of education is that of IT. The problem with this profession can be found in the rapid development of new information technologies. In such a race against time, it is much easier for teachers to introduce English terms and use Latin script directly than to attempt to incorporate the Serbian language and Cyrillic script. However, we believe that a high level of IT expertise should not be a barrier to nurturing native Serbian and Cyrillic. In order to preserve Cyrillic script, the teachers of the College, and beyond, need to cherish it more. This can also have a positive impact on students as shown in our case.

\section{CONCLUSION}

In our study on the usage of Cyrillic script in the educational process by the students at the ICT College, conducted on a selected group of students and their papers, the obtained results have indicated that $59 \%$ of the students used Cyrillic. This percentage is rather high given that the predominant field of education at the College is that of IT. In the field of IT, English is the native language of the profession, which entails the intensive use of Latin script.

The results were provided by a direct inspection of the students' papers. This approach is direct and objective because the students were able to opt for the script quite spontaneously, without any special emphasis on the script concerned. In contrast, the common studies on the use of information technologies in our country and worldwide, including the usage of Cyrillic script, apply surveys whereby sampled respondents provide answers to the questions asked (Informatics Association of Serbia, 2018; Josanov \& Djurić-Kuzmanović, 2004; Statistical Office of the Republic of Serbia 2017a, 2017b). However, it should be especially emphasized that the professors whose courses were herein analysed use Cyrillic script intensively in teaching and thus, probably indirectly, influence their students.

According to the results of the survey on the use of Cyrillic websites by the selected organizations from our country, predominantly from the field of science and education, which was con- 
ducted by the Informatics Association of Serbia, 57\% of them have their websites available in Cyrillic. The above findings are not quite good since they show that those who should take care of the people's identity, their knowledge and literacy, thus cherishing the Serbian language and its original, i.e. traditional Serbian Cyrillic script, do not put enough efforts into it.

The knowledge of new information technologies is an indisputable task of education; however, it should not undermine the basic knowledge of the native Serbian language and Cyrillic script. These two are not contradictory and they should not clash with each other. An increased percentage of the usage of Cyrillic script in IT teaching can be achieved through a greater involvement of teachers at all levels of the education system and in all courses, including the professional ones, in respect to the Serbian language and Cyrillic script. This is not easy because the profession does its part. It is much easier for teachers to directly introduce and use English terms and Latin script in the field of emerging technologies. Nevertheless, they should make an extra effort on this issue as their mission is to expand their students' knowledge in any field. The best method to direct students toward the Serbian language and Cyrillic script is to act as a role model without major proclamations, as shown in our research.

\section{REFERENCES}

Association for defending the Cyrillic alphabet "Dobrica Erić". (2011). Retrieved from www. cirilica-beograd.rs

"Cherish the Serbian Language” campaign. (2015). Retrieved from www.bgb.rs/index.php/component/content/article/2.-uncategorized/695-n-gu-sprs-i-zi

Constitution of the Republic of Serbia. (2006). Retrieved from www.srbija.gov.rs/cinjenice-o-srbiji/ustav-php

Constitutional Court of the Republic of Serbia. (1963). Retrieved from www.ustavni.sud.rs/ page/view/139-100028/ustav-republike-srbije

"Draft of the Cultural Development Strategy". (2017). RTS (Radio Television of Serbia). Retrieved from www.rts.rs/page/stories/ci/story/124/drustvo/ 2764362/zastita-cirilice-i-jezika-vazni-za-kulturoloski-opstanak-drustva.html

ICT College of Applied Studies, Belgrade. (2007). Retrieved from https://www.ict.edu.rs

Jošanov, B. i Đurić-Kuzmanović, T. (2004). Rodne razlike u upotrebi računara, uspehu na ispitima i istraživačkom radu u ICT i E-biznisu. CDROM Zbornik radova, YU iNFO, E-Society, Kopaonik, 2004, 16 (1-5).

Marković N. i Bečejski Vujaklija D. (2018). Anketa o korišćenju ćirilice na Internetu. Informatics Association of Serbia. Društvo za informatiku Srbije. Retrieved from http://dis.org.rs/ $\mathrm{sr} /$ ? $=$ anketacir

Mihajlović, Z. \& Ognjanović, J. (2006). Jedna analiza o tome da li znamo da koristimo baze podataka. CDROM Zbornik radova, YU iNFO 2006, Internet i E-Society, Kopaonik, 6-10th March, 2006, 133 (1-4). ISBN 86-85525-01.

Statistical Office of the Republic of Serbia. Republički zavod za statistiku, Republika Srbija (2017a). Informacione tehnologije. Statistički godišnjak Republike Srbije, 2017, 17. Poglavlje. Beograd.

Statistical Office of the Republic of Serbia. Republički zavod za statistiku, Republika Srbija (2017b). Upotreba informaciono-komunikacionih tehnologija u Republici Srbiji. Beograd. 